\title{
0078. Establishing a detailed short-term rat model of partial ischaemia/reperfusion injury
}

\author{
G Sabbatini*, A Dyson, M Singer \\ From ESICM LIVES 2014 \\ Barcelona, Spain. 27 September - 1 October 2014
}

\section{Introduction}

Liver ischaemia/reperfusion (I/R) injury may be observed after major hepatic surgery or resuscitation from severe trauma/haemorrhage. Well-characterised and representative animal models are needed to better understand mechanisms of injury, apply effective treatments and prevent complications.

\section{Objectives}

To establish a well-characterized rat model of partial liver $\mathrm{I} / \mathrm{R}$ injury.

\section{Methods}

Under isoflurane anaesthesia, tracheotomized male Wistar rats underwent left common carotid artery and right jugu-
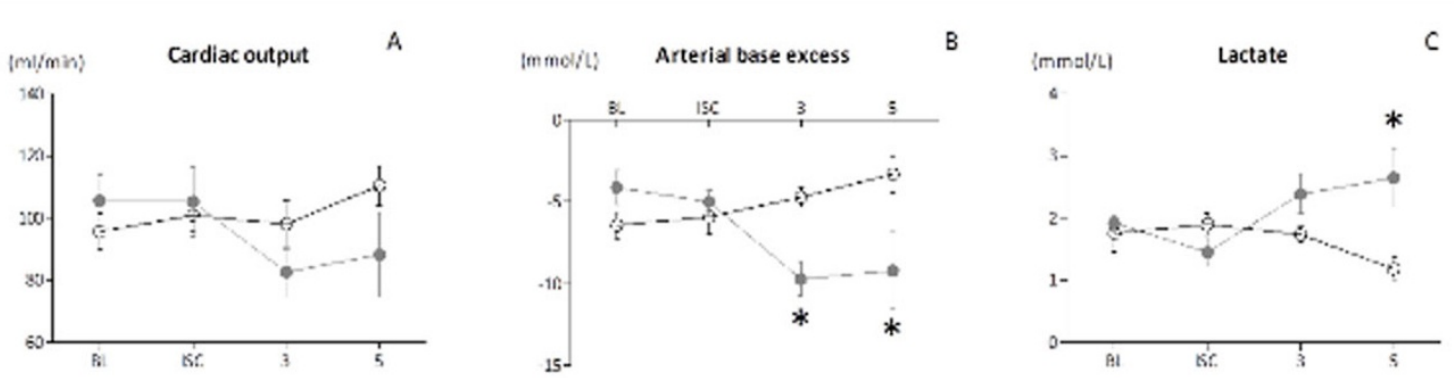

Time (hours)
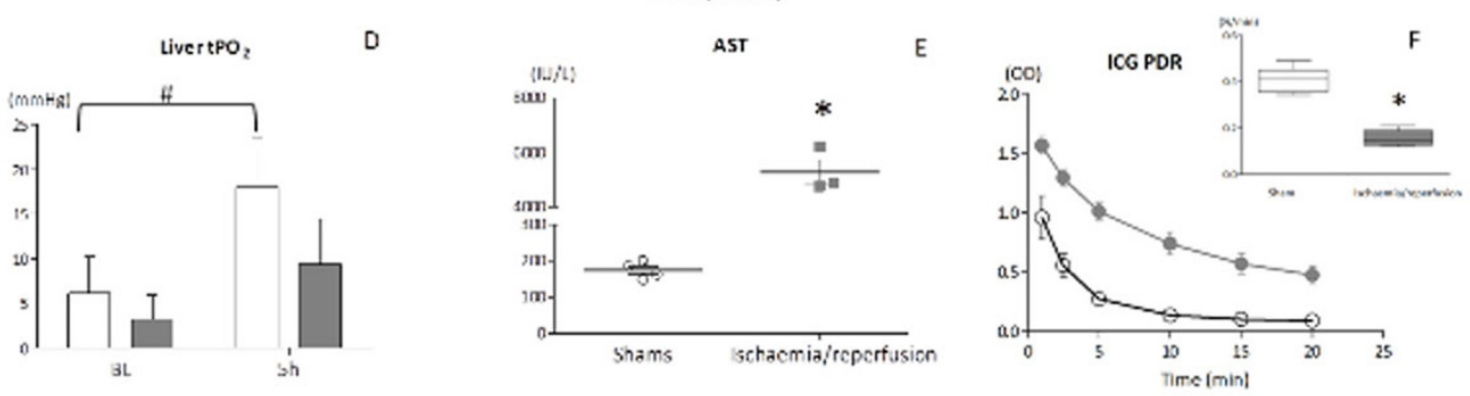

- Sham

- Ischaemia

Figure $1 \mathrm{ISC}=$ Ischaemia, $\mathrm{BL}=$ baseline, $\mathrm{OD}=$ optical density $\mathrm{AST}=$ aspartate aminotransferase. Data shown as mean (SEM) (A-E) or median (interquartile range) (F). Sham =6, Ischaemia = 5/group, ${ }^{*} p<0.05$ comparing ischaemia to sham, \#p<0.05 comparing BL to 5h. Statistics performed using t-test or two-way ANOVA and Bonferroni's test for multiple comparisons, as appropriate. 
lar vein instrumentation for BP measurement/blood sampling and fluid infusion $(10 \mathrm{ml} / \mathrm{kg} / \mathrm{hr})$, respectively, and bladder catheterization for urine output measurement. Via a transverse subcostal laparotomy, blood vessels to the median and left liver lobes were occluded with a surgical clamp for 60 mins. On release of the clamp, the remaining liver lobes were ligated to prevent a steal phenomenon. The animals were observed for a further 5 hours. Sham animals underwent the same procedure except for vascular occlusion. Measurements were made of haemodynamics (BP, echocardiography), blood gas analysis, and biochemical and functional (Indocyanine Green plasma disappearance rate, ICG-PDR) liver function tests. A tissue $\mathrm{PO}_{2}$ probe $\left(\mathrm{tPO}_{2}\right)(\mathrm{Oxford}$ Optronix, UK) was placed in contact with liver tissue to measure hepatic tissue $\mathrm{PO}_{2}$. Tissue samples were taken to assess microscopic and ultrastructural injury both locally and remotely (data not shown).

\section{Results}

See figure 1.

Liver ischaemia resulted in an increase of markers of hepatic injury (AST) and function (ICG-PDR and Lactate). Cardiac output was maintained but arterial base excess was different between groups. $\mathrm{tPO}_{2}$ at 5 hours post-reperfusion recovered in shams but not in $I / R$ group.

\section{Conclusions}

This severe liver I/R model demonstrates derangement of hepatic function, biochemistry, haemodynamic and ultrastructure. It offers utility for the assessment of interventions aimed at preventing or reducing I/R injury.
Published: 26 September 2014

\section{References}

1. Eguchi S, Kamlot A, Ljubimova J, Hewitt WR, Lebow LT, Demetriou AA, Rozga J: Fulminant hepatic failure in rats: survival and effect on blood chemistry and liver regeneration. Hepatology 1996, 24(6):1452-1459.

2. Merle U, Sieg O, Stremmel W, Encke J, Eisenbach C: Sensitivity and specificity of plasma disappearance rate of indocyanine green as a prognostic indicator in acute liver failure. BMC Gastroenterology 2009, 9:91.

doi:10.1186/2197-425X-2-S1-P1

Cite this article as: Sabbatini et al:: 0078. Establishing a detailed shortterm rat model of partial ischaemia/reperfusion injury. Intensive Care Medicine Experimental 2014 2(Suppl 1):P1.

\section{Submit your manuscript to a SpringerOpen ${ }^{\mathcal{O}}$ journal and benefit from:}

- Convenient online submission

- Rigorous peer review

- Immediate publication on acceptance

- Open access: articles freely available online

- High visibility within the field

- Retaining the copyright to your article

Submit your next manuscript at $>$ springeropen.com 